\title{
PROMOTING SUSTAINABILITY THROUGH INNOVATION: CONVERSION OF WOOD WASTE TO PELLETS
}

\author{
Ngozi N. Okorie .*1,Akinola D. Olugbemide ${ }^{4}$, Victoria O. Akpambang ${ }^{3}$, Las Agbetoye ${ }^{2}$, \\ Afamefuna E. Okoronkwo ${ }^{3}$ \\ National Agency for Science and Engineering Infrastructure, Centre for Excellence in Nanotechnology \& Advanced \\ Materials, Akure, Ondo State, Nigeria ${ }^{1}$
}

Agricultural Engineering Department, Federal University of Technology, Akure, Ondo state, Nigeria ${ }^{2}$

Department of Chemistry, Federal University of Technology, Akure, Ondo State, Nigeria ${ }^{3}$

Department of Basic Sciences, Auchi Polytechnic, Auchi, Edo State, Nigeria ${ }^{4}$

\begin{abstract}
Sustainability could be achieved by applying technological innovation to scientific principles. Applying knowledge-based capacity in creatively solving societal problems and as such provide economic empowerment. In this study, wood wastes (sawdust samples) Cetis africana (Ita white); Cordina millenni (Omo Sheda), and mixed sawdust (unclassified) were characterized for optimum condition and made into pellets. An in-house pelletiser of shape factor 2.78 was fabricated for this production. The particle size, binder modification, combustible properties, and calorific value showed that a sample with $\mathrm{x} \leq 600 \mu \mathrm{m}, 30 \% \mathrm{w} / \mathrm{v}$ binder concentration at a compressive pressure of $6.2 \mathrm{Nm}^{-2}$ gave the best result. The mixed sawdust sample gave results that were not consistent, requiring a proper initial understanding or sorting out. Cetis africana was observed as the best sample with good pellet quality that can be used in different heating systems. Meeting societal problems such as effective waste management aimed at curbing the negative impact of greenhouse gas emission on the environment and power generation in distributed form can be fast-tracked through innovative research and development which must be commercialised thus financially empowering the society at large.
\end{abstract}

Keywords: Sustainability, Technological innovation, Waste to wealth, Commercialisation

\section{INTRODUCTION}

Sustainability can only be achieved by mainstreaming innovation and mentoring upcoming Engineers and Scientists to think innovatively. This goes beyond departmentalisation but exposing students to an interdisciplinary way of handling issues as students and in preparation for life after school. Technopreneurship is a system of mainstreaming technological innovation towards achieving sustainability in various sector and economies of the world (Rajalingam, 2014; Okorie et al., 2014). This involves capacity building, networking, marketing, project teams, and interdepartmental learning that will produce citizens that are entrepreneurial and have a competitive edge. This will equip even students to be proactive, looking out for ways of using their knowledge-based capacity to solve societal problems.

According to Steven Sutantro, as reported by McClure (2015), innovation is about applying technology to empower young people to become lifelong learners who are agents of change. One such innovative works is seeking to convert waste to wealth by turning sawdust to pellet for both industrial and domestic energy use. The research will no longer end only in publications that will in turn end on the shelves but be target-oriented in meeting societal needs. Graduates will no longer come out and be job seekers but problem solvers and employers of labour through various innovations (Rajalingam, 2014).

European Union presented some climate and energy targets to be achieved by the year 2030 which gave room for the contribution of renewable energy to the energy mix around the world and the increase in the demand for pellets (Whittaker and Shield, 2017). Biomass stands out among the renewable energy sources that are available for the achievement of these goals. Densification of biomass is crucial in minimizing the disadvantages associated with the use of biomass such as low density, high moisture content, handling, and storage (Malik et al., 2015; Tumuluru. 2014). This can be achieved through briquetting, pelletizing, or agglomeration (Mitchual, 2014). The interest in pelletizing has increased over the years between 2006 and 2012. Pellet production worldwide grew from 7 to 19 million tons with Europe and North America being the highest producer and consumer of these classified products. These have given rise to the introduction of new materials as feedstock and the development of quality standards that will help to guarantee 


\section{International Advanced Research Journal in Science, Engineering and Technology}

Vol. 8, Issue 4, April 2021

DOI: $10.17148 /$ IARJSET.2021.8465

the right use of different types of pellet in combustion equipment with the introduction of new classification (Miranda et al.,2015).

A wide range of study has been done on the densification of materials due to high availability of different types of biomass and the need to adapt them to specific uses. Pelletisation helps to produce biofuels with lower moisture, dense and relatively uniform shape, having higher effective heating value, with clear burning and reduced ashes when compared with raw biomass (Ungureanu et al., 2018). This process produces pellets which can be used in different energy conversion units such as boilers, engines, and gas turbines even fuel cells (Koukouzas et al., 2008). To produce quality pellets, two things must be considered; the characteristics of the raw materials to be used as feedstock and the operational variables in the densification process (Garcia- Maraver and Carpio, 2015; Harun 2018). These parameters include biomass type, moisture content, particle size, operating conditions, pelletiser type, die diameter, shape factor (L/D), and a binding agent ( Stahl et al.,2012; Garcia- Maraver and Carpio, 2015; Tumuluru,2014; Whittaker and Shield,2017; Lisowski et al.,2018).

Lignocellulosic biomass is the major raw material for pellet production (Malik et al., 201). It can also be soft or hardwood species, red or white in colour. The choice of biomass wood waste such as sawdust as feedstock would mitigate the problem of deforestation. The physical and chemical compositions of the biomass type (raw material) affect greatly the quality of the pellets (Malik et al., 2015 Liu et al., 2014; Garcia - Maraver and Carpio, 2015). They include moisture content, ash content, mineral analysis, particle size, shape, and calorific value. All these variables and as well as the intended use of the pellets influence the choice of wood species for pellet production (Mitchual, 2014). Whittaker and Shield (2017) in their review concluded that softwood is believed to give higher quality pellets than hardwood due to its high lignin content but with binders supplying additional lignin, good quality hardwood pellets can be formed.

Particle size is an important parameter in determining the hardness of pellets and this must be considered (Whittaker \& Shield, 2017; Adapa et al., 2013). It affects the total surface area; pore size and number of contact points for interparticle bonding that is necessary to produce good quality pellets (Ungureanu et al., 2018). Many researchers have worked on identifying the optimum particle sizes for different biomass materials to produce the best quality pellets (Miranda et al., 2015).

Samples with low ash content, and relatively high bulk densities are preferred (Khan et al., 2017). The moisture content is an important factor in determining the quality and burning characteristics of pellets (kitimbo et al., 2014). It is required at the lowest optimum. The colour of the wood sample also influences the choice of wood. Cetis africana (Ita white) is white in colour and Cordina milleni (Omo Sheda) is a redwood sample.

The target of the pellets in this work is to serve as feedstock for a gasification operation in a downdraft gasifier to generate gaseous fuel. Three out of eight wood species of sawdust samples studied previously(under review) were selected for this work, with a conclusion that lignocelluloses wood waste materials are made up of different chemical properties even within the sample of same species is in agreement with Garcia- Maraver and Carpio, (2015). The selection favoured majorly the hardwood sawdust and the mixed sawdust. Mixed sawdust here refers to mixtures unclassified (mixed without intension), which is the most common state available on site.

\section{Feedstock Preparation}

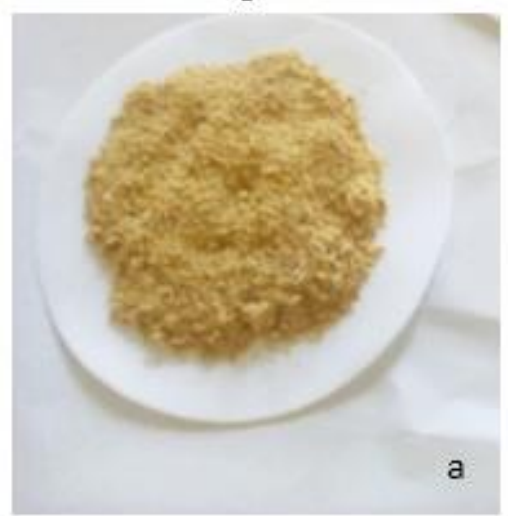

\section{MATERIALS AND METHODS}

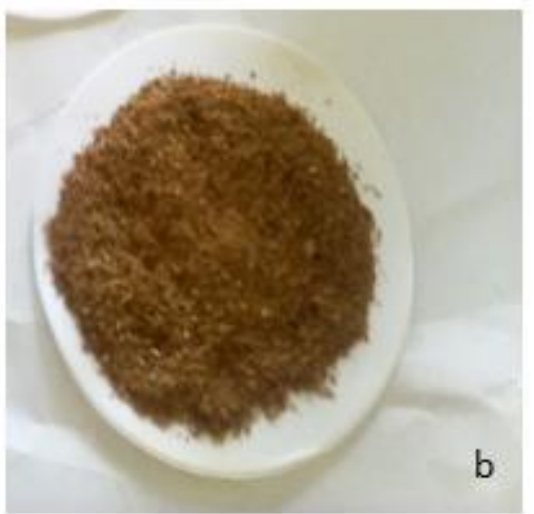

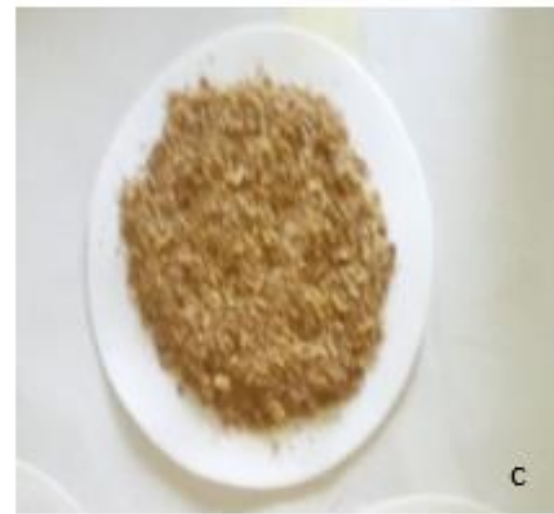

Figure 1. Images of the feedstock (a) Cetis africana (Ita white);(b) Cordina milleni (Omo Sheda); (c) Mixed sawdust Fresh wet sawdust samples of Cetis africana (Ita white); Cordina milleni (Omo Sheda) and Mixed sawdust samples were sun-dried for three days to reduce moisture. The dried samples were sieved using an Octagonal sieve shaker using a set of 5 sieves screen. Sample retained in $600 \mu \mathrm{m}$ and $850 \mu \mathrm{m}$ were selected for pellet making and others were treated as undersize and oversize materials. These were store in an airtight ziploc bag for further analysis. 


\section{International Advanced Research Journal in Science, Engineering and Technology}

Vol. 8, Issue 4, April 2021

DOI: $10.17148 /$ IARJSET.2021.8465

\section{Pellet Formation}

The pellets were made in an in- house constructed pelletiser designed specifically for this work. The pelletiser is a manually operated extruding press with a die of diameter $37 \mathrm{~mm}$ and length of $103 \mathrm{~mm}$, operating at an average of $177.6 \mathrm{rpm}$. The rpm was determined using a non- contact digital tachometer (Model T445019). The two-particle sizes for the three sawdust samples of known mass were mixed manually with the binder at different concentrations $(20,25$, $30,35,40 \% \mathrm{w} / \mathrm{w})$ selected for the process. The mixture is fed in and extruded through the machine and the pellets made by cold compression (Mitchual, 2014). The freshly formed cylindrical pellets were made to dry in ambient temperature uniformly and effectively for $48 \mathrm{hrs}$ to avoid cracks. Pellets were kept for about two to three weeks at a temperature of $27^{\circ} \mathrm{C}$ and a humidity of $50 \%$ (Liu et al., 2014) to achieve a stable parameter before further analysis. The optimum moisture content of the pellet made was determined and the pellets stored in a vacuum container. Pellets were randomly selected from each trial for further analysis.

\section{Pellet Dimensions}

\section{PELLET CHARACTERISATION}

The dimension, average length (L) and average diameter (D) of the randomly selected pellets were determined with three pellet sample each of the 23 selected concentration of binders by using a venire calliper according to the work done by Liu et al., (2016). The ends of the randomly selected pellets were treated with an abrasive to give them a smooth cylindrical edge before measurements were taken. The length was taken in accordance with the Handbook of Biomass Gasification as recorded by Brandin et al., (2011) and Tumuluru (2014). The mass of each pellet was determined by weighing in a precision digital balance. This was repeated for three sawdust sample.

The Shape correlation factor given by the ratio of length to diameter (L/D) was determined according to the method described by Biswas and Umeki, 2005; Garcia- Maraver and Carpio, 2015.

\section{Pellet Density}

The unit density $\left(\mathrm{P} \mathrm{km}^{-3}\right)$ of the pellet was determined; this was done randomly for each concentration of binder and experiment repeated in triplicate following Tumuluru (2014).

\section{Bulk density}

Bulk density $P_{b}\left(\mathrm{~km}^{-3}\right)$ was determined according to Liu et al., 2014.

\section{Compressive Strength}

The mechanical strength of the pellets was analyzed by conducting the compressive test for the two different particle sizes at different concentration. The randomly selected pellets from similar texture were cut to obtain a flat surface with an averagely uniform length. The die-diameter of $35 \mathrm{~mm}$ and $98 \mathrm{~mm}$ length was used for the test. Twenty three pellet samples were tested and the experiment was carried out in triplicates. Compressive strength of the pellets was plotted against the various concentrations for the 3 samples at selected particle sizes. The ultimate compressive strength was plotted for the best pellet strength.

\section{Combustion Test}

The combustion test of the pellets was conducted using a household eco-stove as described by Jindaporn and Charoenporn with modifications. Five (5) pellets each were arranged in the stove such that air passage is not blocked. The heat generated was used to boil two (2) litres of water. The temperature of the system was monitored with a thermocouple which was calibrated with chemicals of known melting point. The smoke emission of the pellet fuels was observed during the process. The overall efficiency of the process was reported. This was observed for the three (3) selected concentrations $(20,30,40)$ for the three (3) types of pellet source. The particle size used was $600 \mu \mathrm{m}$ retained. Ignition Time, $\mathrm{t}_{2}=\mathrm{t}_{1}-\mathrm{t}_{0}$

Water boiling Time $=\left[t_{3}-t_{2}\right]$

Total Duration $=\left[\mathrm{t}_{4}-\mathrm{t}_{1}\right] \mathrm{min}$

Where $\mathrm{t}_{1}=$ time the pellet stabilized for use $(\mathrm{min}), \mathrm{t}_{0=}$ time the pellet stove was lighted ( $\left.\mathrm{min}\right)$

Where $t_{2}=$ Ignition time $(\min ), t_{3}=$ time the water boils (min)

Where $t_{4}=$ Pellet burn out time $(\min ), t_{1}=$ time the pellet stabilized for use $(\mathrm{min})$.

\section{Surface Analysis}

The morphological changes during pelletizing and the effect of binder concentrations on the binding structure of the pellets were investigated using a scanning electron microscope (SEM). From the result of the compressive strength of the sample, the concentration with the best compressive strength (XA3) was studied and compared with two others the raw sample (XA0) and the sample with the least binder concentration (XA1).

\section{Calorific Value}

The heat value for the pellets was determined using an oxygen bomb calorimeter model E2K - Bomb Calorimeter. The determination was done for the two (2) types of pellet sources and particle size $\mathrm{X}=600 \mu \mathrm{m}$ retained. $\mathrm{A}=$ Cetis africana (Ita white), B= Cordina milleni (Omo Sheda) (XA, XA3, XA4, XA5) and (XB, XB3, XB4, XB5). The determination 


\section{International Advanced Research Journal in Science, Engineering and Technology}

Vol. 8, Issue 4, April 2021

DOI: $10.17148 /$ IARJSET.2021.8465

was done for the raw wood waste sample and the pellets at different binder concentration. The result was compared with the computed calorific value of the raw sample.

\section{Statistical Analysis}

The statistical analyses for the results were done using statistical package for Social science IBM SPSS version 23 . The results obtained from different pellet produces were compared using one-way analysis of variance (ANOVA). The means were compared using Duncan Multiple Range Test. Results were expressed as mean \pm standard deviation with values of $\mathrm{p}<0.05$ considered as significant.

\section{RESULTS}

\section{Raw Materials}

Figure 1 shows the images of the raw samples of the selected lignocelluloses wood waste. Table 1 shows the physicochemical properties of the sample.

Table 1. Property of Raw materials before Pellet Formation

\begin{tabular}{|c|c|c|c|c|c|c|c|}
\hline Sample & $\begin{array}{l}\text { Miosture Content } \\
(\% \mathrm{db})\end{array}$ & $\begin{array}{l}\text { Bulk } \\
\text { Density } \\
\left(\mathrm{kg} / \mathrm{m}^{3}\right)\end{array}$ & $\begin{array}{l}\text { Ash Content } \\
(\% \mathrm{db})\end{array}$ & Fixed Carbon & $\begin{array}{l}\text { Volatile } \\
\text { Matter }\end{array}$ & $\begin{array}{l}\text { Particle } \\
(\mu \mathrm{m})\end{array}$ & size \\
\hline A & $10.85 \pm 2.24$ & $234.00^{\mathrm{f}} \pm 3.0$ & $1.93^{\mathrm{d}} \pm 0.15$ & $9.70^{c} \pm 0.17$ & $88.37^{\mathrm{e}} \pm 0.06$ & $\begin{array}{r}X \leq 600 \\
Y \leq 850\end{array}$ & \\
\hline B & $11.28 \pm 0.57$ & $199.70^{\mathrm{e}} \pm 1.5$ & $1.33^{\mathrm{b}} \pm 0.23$ & $10.50^{\mathrm{d}} \pm 0.30$ & $88.17^{\mathrm{d}} \pm 0.15$ & $\begin{array}{l}X \leq 600 \\
Y \leq 850\end{array}$ & \\
\hline $\mathrm{C}$ & $9.97 \pm 2.24$ & $\begin{array}{l}163.70^{\mathrm{d}} \pm 24 \\
50\end{array}$ & $1.53^{\mathrm{c}} \pm 0.32$ & $9.78^{\mathrm{c}} \pm 0.35$ & $88.70^{f} \pm 0.10$ & $\begin{array}{l}X \leq 600 \\
Y \leq 850\end{array}$ & \\
\hline
\end{tabular}

Note: $A=$ Cetis africana(Ita white $) ; B=$ Cordina milleni $($ Omo Sheda $) ; C=$ Mixture

The particle size range of $\mathbf{X} \leq 600 \mu \mathrm{m}$ and $\mathbf{Y} \leq 85 \mu \mathrm{m}$ agreed to the recommended sizes range for quality pellets (Khan et al., 2017; Whittaker and Shield, 2017). The initial moisture content (MC) of the samples (sample A has MC as $10.85 \pm 2.24$, B as $11.28 \pm 0.57$ and $\mathrm{C}$ as $9.97 \pm 2.24$ ). This was determined prior to pelletizing the operation to get the optimal moisture content range of 10\% - 15\% for pellet making (Ajobo, 2014; Lu et al., 2014; Ungureanu et al., 2018). This is vital in ensuring pellet quality (Arzola et al., 2012; Kitimbo et al., 2014; Whittaker and Shield, 2017; Harun et al., 2018). The optimal moisture content needed to be determined and maintained because above this optimal, combustion heat will be partially lost in evaporating water from pellet in the combustion chamber and the shelf life of the pellets will be hindered with a high rate of degradation as was observed (Fig 2) and below its reaction between the particles will be hindered.

\section{Pellet Properties}

Figure 3 and 4 show various pellets produced at different binder concentration and at different particle sizes. Table 2 shows the mean value of the properties of the pellets.
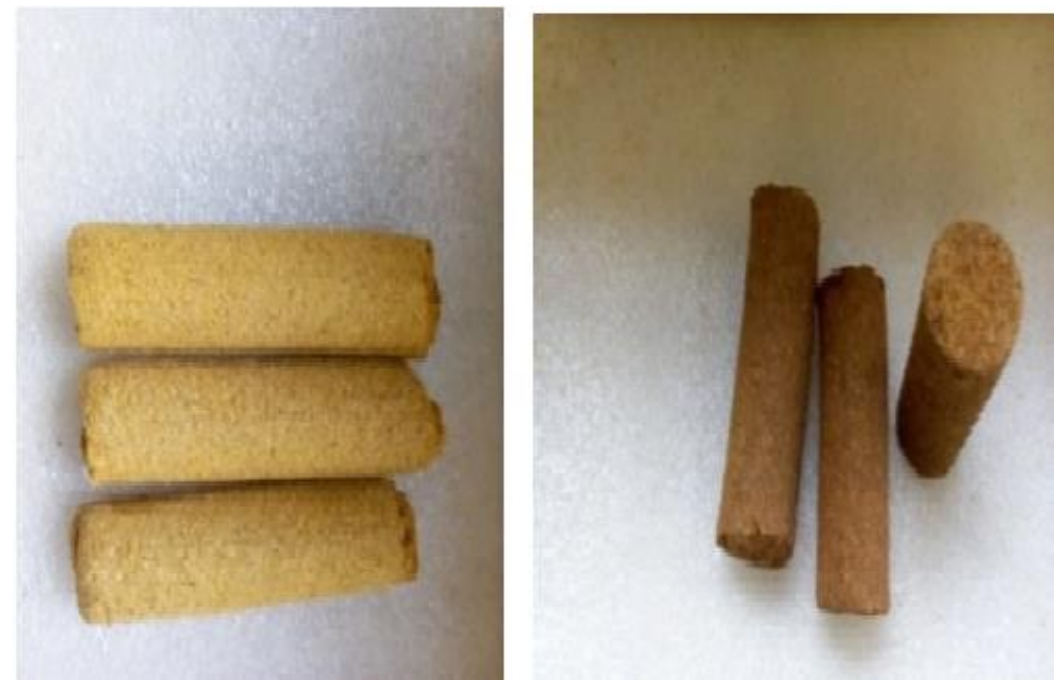

Figure 3:Pellets from different Species at $600 \mu \mathrm{m}$ and properly dried 
International Advanced Research Journal in Science, Engineering and Technology

Vol. 8, Issue 4, April 2021

DOI: $10.17148 / I A R J S E T .2021 .8465$

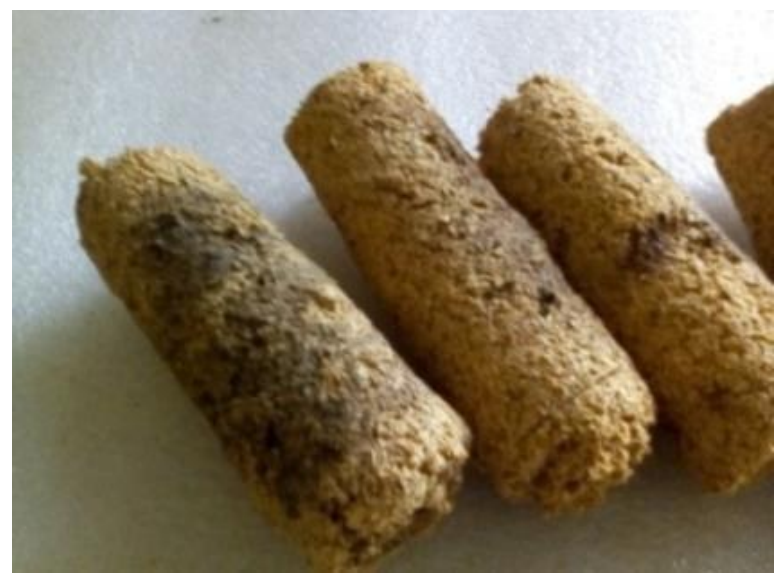

Figure 4: Pellets from a Specie at $850 \mu \mathrm{m}$ particle size with degradation as a result of moisture not drying effectively to the desired optimal.

Table2. Pellet Properties

\begin{tabular}{lccccc}
\hline Pellet Property & \multicolumn{5}{c}{ Length $(\mathbf{m m})$} \\
\hline Binder Conc $(\%$ w/w) & 20 & 25 & 30 & 35 & 40 \\
\hline AX & $98.17 \pm 0.76 \mathrm{a}$ & $98.17 \pm 0.76 \mathrm{a}$ & $96.00 \pm 1.32^{\mathrm{a}}$ & $97.70 \pm 1.93^{\mathrm{a}}$ & $97.33 \pm 3.21^{\mathrm{a}}$ \\
AY & $98.10 \pm 0.96^{\mathrm{ab}}$ & $95.83 \pm 3.33^{\mathrm{ab}}$ & $95.67 \pm 1.15^{\mathrm{b}}$ & $99.57 \pm 0.93^{\mathrm{a}}$ & $98.37 \pm 2.12^{\mathrm{a}}$ \\
BX & $95.50 \pm 0.87^{\mathrm{a}}$ & $95.33 \pm 1.53^{\mathrm{a}}$ & $95.63 \pm 0.32^{\mathrm{a}}$ & $97.17 \pm 1.04^{\mathrm{a}}$ & $95.80 \pm 0.75^{\mathrm{a}}$ \\
BY & $96.50 \pm 1.00^{\mathrm{bc}}$ & $95.33 \pm 2.02^{\mathrm{c}}$ & $100.17 \pm 0.76^{\mathrm{a}}$ & $95.17 \pm 1.04^{\mathrm{c}}$ & $98.00 \pm 0.50^{\mathrm{b}}$ \\
CX & - & - & $98.33 \pm 1.04^{\mathrm{b}}$ & $96.93 \pm 1.75^{\mathrm{b}}$ & $101.17 \pm 2.75^{\mathrm{a}}$ \\
\hline
\end{tabular}

Pellet Property

Diameter (mm)

\begin{tabular}{|c|c|c|c|c|c|}
\hline Binder Conc $(\% \mathrm{w} / \mathrm{w})$ & 20 & 25 & 30 & 35 & 40 \\
\hline $\mathrm{AX}$ & $\begin{array}{c}36.17 \pm \\
0.29^{\mathrm{a}}\end{array}$ & $34.93 \pm 0.12^{\mathrm{b}}$ & $33.67 \pm 0.58^{\mathrm{c}}$ & $35.17 \pm 0.29^{b}$ & $36.07 \pm 0.12^{\mathrm{b}}$ \\
\hline AY & $\begin{array}{c}36.17 \pm \\
0.58^{\mathrm{a}}\end{array}$ & $35.47 \pm 0.55^{\mathrm{a}}$ & $36.67 \pm 0.29^{\mathrm{a}}$ & $35.70 \pm 0.72^{a}$ & $34.87 \pm 0.32^{\mathrm{a}}$ \\
\hline $\mathrm{BX}$ & $\begin{array}{c}35.17 \pm \\
0.29^{\mathrm{a}}\end{array}$ & $35.00 \pm 0.50^{\mathrm{ab}}$ & $34.50 \pm 0.87^{\mathrm{ab}}$ & $34.83 \pm 0.29^{\mathrm{ab}}$ & $33.90 \pm 0.66^{\mathrm{b}}$ \\
\hline BY & $\begin{array}{c}34.97 \pm \\
0.58^{\mathrm{a}}\end{array}$ & $34.60 \pm 0.70^{\mathrm{a}}$ & $34.33 \pm 0.29^{\mathrm{a}}$ & $34.03 \pm 1.36^{\mathrm{a}}$ & $35.00 \pm 0.00^{\mathrm{a}}$ \\
\hline $\mathrm{CX}$ & - & - & $36.17 \pm 0.29^{b}$ & $37.00+0.87^{\mathrm{a}}$ & $34.67+0.29^{c}$ \\
\hline
\end{tabular}

Pellet Property

Shape factor $\mathrm{L} / \mathrm{D}$

\begin{tabular}{|c|c|c|c|c|c|}
\hline Binder Conc $(\% \mathrm{w} / \mathrm{w})$ & 20 & 25 & 30 & 35 & 40 \\
\hline $\mathrm{AX}$ & $2.71 \pm 0.36^{b}$ & $2.81 \pm 0.17^{\mathrm{ab}}$ & $2.85 \pm 0.87^{\mathrm{a}}$ & $2.78+0.50^{\mathrm{ab}}$ & $2.75 \pm 0.99^{\mathrm{ab}}$ \\
\hline AY & $\begin{array}{c}2 . \overline{7} 5 \pm \\
0.35^{\mathrm{a}}\end{array}$ & $2.70 \pm 0.11^{\mathrm{a}}$ & $2.64 \pm 0.05^{\mathrm{b}}$ & $2.79 \pm 0.06^{\mathrm{a}}$ & $2.82 \pm 0.04^{\mathrm{a}}$ \\
\hline BX & $2.71 \frac{+0.05}{b}$ & $2.72+0.06^{\mathrm{ab}}$ & $2.77 \pm 0.07^{\mathrm{ab}}$ & $2.79 \pm 0.01^{\mathrm{ab}}$ & $2.83+0.55^{\mathrm{a}}$ \\
\hline BY & $\begin{array}{l}2.76 \pm \\
0.03^{\mathrm{a}}\end{array}$ & $2.75 \pm 0.03^{\mathrm{a}}$ & $2.80 \pm 0.09^{\mathrm{a}}$ & $2.80 \pm 0.08^{a}$ & $2.80 \pm 0.01^{\mathrm{a}}$ \\
\hline CX & - & - & $2.72+0.04^{b}$ & $2.62+0.09^{b}$ & $2.94+0.11^{\mathrm{a}}$ \\
\hline
\end{tabular}

Pellet Property

\begin{tabular}{|c|c|c|c|c|c|}
\hline $\begin{array}{l}\text { Binder Conc (\% } \\
\text { w/w) }\end{array}$ & 20 & 25 & 30 & 35 & 40 \\
\hline $\mathrm{AX}$ & $48.99 \pm 1.60^{c}$ & $49.76 \pm 0.15^{c}$ & $55.30 \pm \frac{\mathrm{b}}{0.54}$ & $57.68 \pm 0.71^{b}$ & $64.28 \pm 2.32^{\mathrm{a}}$ \\
\hline AY & $44.47 \pm 0.74^{\mathrm{ab}}$ & $47.78 \pm 1.8^{b}$ & $\begin{array}{c}55.29 \pm \\
1.15^{\mathrm{ab}}\end{array}$ & $59.85 \pm 1.09^{\mathrm{ab}}$ & $62.49 \pm 1.61^{\mathrm{a}}$ \\
\hline $\mathrm{BX}$ & $43.86+0.23^{e}$ & $49.68+1.44^{\mathrm{d}}$ & $51.80+0.13^{c}$ & $53.87 \pm 0.21^{b}$ & $59.87 \pm 0.9^{\mathrm{a}}$ \\
\hline
\end{tabular}


International Advanced Research Journal in Science, Engineering and Technology

Vol. 8, Issue 4, April 2021

DOI: $10.17148 / I A R J S E T .2021 .8465$

\begin{tabular}{|c|c|c|c|c|c|}
\hline $\begin{array}{l}\text { BY } \\
\text { CX }\end{array}$ & $\begin{array}{c}43.38 \pm 0.61^{\mathrm{c}} \\
-\end{array}$ & $\begin{array}{c}44.90 \pm 2.81^{\mathrm{c}} \\
- \\
\end{array}$ & $\begin{array}{l}+1.15^{\mathrm{b}} \\
+1.39^{\mathrm{b}} \\
\end{array}$ & $\begin{array}{l}58.19 \pm 3.69^{\mathrm{b}} \\
52.00 \pm 0.86^{\mathrm{a}} \\
\end{array}$ & $\begin{array}{l}62.49 \pm 1.61^{\mathrm{a}} \\
53.87 \pm 2.05^{\mathrm{a}} \\
\end{array}$ \\
\hline Pellet Property & \multicolumn{5}{|c|}{ Density $\left(\mathrm{kg} / \mathrm{m}^{3}\right)$} \\
\hline $\begin{array}{l}\text { Binder Conc } \\
(\% \mathrm{w} / \mathrm{w})\end{array}$ & 20 & 25 & 30 & 35 & 40 \\
\hline $\mathrm{AX}$ & $486.17 \pm 21.80^{\mathrm{c}}$ & $528.83 \pm 8.67^{\mathrm{c}}$ & $\begin{array}{r}647.27 \pm \\
17.02^{\mathrm{a}}\end{array}$ & $\begin{array}{c}608.03 \pm+ \\
16.57^{\mathrm{b}}\end{array}$ & $684.57 \pm 42.34^{\mathrm{a}}$ \\
\hline AY & $441.50 \pm 17.43^{\mathrm{ab}}$ & $\begin{array}{c}504.97 \pm \\
20.92^{\mathrm{ab}}\end{array}$ & $\begin{array}{c}547.67 \pm \\
26.08^{\mathrm{ab}}\end{array}$ & $\begin{array}{l}601.23 \pm \\
33.77^{\mathrm{ab}}\end{array}$ & $665.33 \pm 11.93^{\mathrm{a}}$ \\
\hline $\mathrm{BX}$ & $472.87 \pm 4.80^{c}$ & $\begin{array}{c}542.03 \pm \\
28.05^{\mathrm{b}}\end{array}$ & $\begin{array}{c}579.93 \pm \\
26.11^{\mathrm{b}}\end{array}$ & $\begin{array}{c}581.93 \pm \\
17.55^{\mathrm{b}}\end{array}$ & $692.80 \pm 27.52^{\mathrm{a}}$ \\
\hline BY & $468.00 \pm 3.50^{c}$ & $\begin{array}{r}502.80 \pm \\
61.61^{\mathrm{bc}}\end{array}$ & $\begin{array}{l}596.23 \pm \\
16.21^{\mathrm{ab}}\end{array}$ & $\begin{array}{c}676.87 \pm \\
101.3^{\mathrm{a}}\end{array}$ & $662.73 \pm 19.78^{a}$ \\
\hline CX & - & - & $\begin{array}{r}462.50 \pm \\
15.74^{\mathrm{c}} \\
\end{array}$ & $\begin{array}{c}499.53 \pm \\
28.99^{\mathrm{b}}\end{array}$ & $564.60 \pm 33.97^{\mathrm{a}}$ \\
\hline
\end{tabular}

Values are mean \pm SD of 3 determinants. Values with different superscript across the row indicate significant difference $(\mathrm{p}<0.05)$ Where: Cetis africana (Ita white); $B=$ Cordina milleni (Omo Sheda);C $=$ Mixture. Particle Size $\mathrm{X}=600 \mu \mathrm{m} ; \mathrm{Y}=\mathbf{8 5 0 \mu \mathrm { m }}$

The length in Table $2 \mathrm{a}$ varied between 95.17 and $101.17 \mathrm{~mm}$. This length values are larger than the regular commercial pellets (11-17) and diameter (8-10 mm) (Tumuluru, 2014; Biswa and Umeki., 2015). In this work, the in-house pelletiser has a die diameter of $37 \mathrm{~mm}$ and length of 103 , and in turn a shape factor (length to diameter ratio) of about 2.78. This will help increase the pressure needed for the pelletizing process. The pellets showed an increase in length as concentration increased and since the pelletiser has no cutter attached to it thus the length of the pellets formed varied slightly (Stahl et al., 2012). This affected the production rate and the number of pellets in each batch. These process variable was designed to give a small die diameter and a high die length/diameter ratio, that in turn produce pellets with high compressive strength and quality as was observed. This agreed with the recommendations of Tumuluru et al., 2011, Malik et al., 2015 and Whittaker \& Shield, 2017).

The pellet produced in this work has a length $(\mathrm{L})$ and diameter $(\mathrm{D})$ ratio $\leq 4(\mathrm{~L} / \mathrm{D} \leq 4)$. The diameter ranged between $33.67 \mathrm{~mm}-37.00 \mathrm{~mm}$. The mass of the pellets ranged between $43.38-64.28 \mathrm{~kg}$. The shape correlation factor which is the ratio of length to the diameter of pellets ranged between $2.6-2.94$. The ratio is a good metric for the degree of compression experienced by the raw material during pelletizing. Pellet dimension (diameter, length, and or diameter/length ratio) will help determine the pressure required for the process (Garcia-Maraver and Carpio, 2015). The L/D ratio influences the unit density of the pellets as reported by Biswas and Umeki (2015).

\section{Density}

The unit density of the pellets varies between 441 and $692 \mathrm{kgm}^{-3}$. Both unit and bulk density is greatly influenced by the raw material moisture content and its particle size in addition to the concentration of the binder. As can be seen in the table, with a high L/D ratio above 2.50, the density of unit pellets were relatively high above $500 \mathrm{~km}^{-3} \mathrm{except}$ for AX1, AY1, BX1, and BY1with binder concentration 20\%w/v. This confirms the influence of binder concentration on the density of pellets formed. For both samples A and B, density increased as binder concentration increased. Particle size X, $600 \mu \mathrm{m}$ had the highest density when compared with $\mathrm{Y}, 850 \mu \mathrm{m}$, for both samples AX5 $\left(684.51 \pm 42.34 \mathrm{~kg} / \mathrm{m}^{3}\right)$ $>$ AY5 $\left(665.33 \pm 11.93 \mathrm{~kg} / \mathrm{m}^{3}\right)$, BX5 $\left(692.80 \pm 17.55 \mathrm{~kg} / \mathrm{m}^{3}\right)>$ BY5 $\left(662.73 \pm 19.78 \mathrm{~kg} / \mathrm{m}^{3}\right)$. This implies that pellet density decreases as particle size increases. Higher density represents high energy per unit volume of material. (Mirande et al, 2015; Adapa et al., 2015). The bulk density is lower than expected because of the peculiarity of the pellet dimension which is a little bigger than a regular pellet but less than a briquette (Tumuluru; 2014). The density of the pellets also increased with an increase in the amount of binder used. This increase is independent of the variety of binder used as was reported by Stahl et al., 2012 as they compared various varieties of starch.

\section{Compressive Strength}

This provides a quick measure of the quality of pellets. It is the impact resistance that shows the maximum crushing load a pellet can withstand before cracking or breaking (Garcia - Maraver and Carpio, 2015). It determines the stability and durability of densified materials and is largely affected by the particle size of the feedstock (Onukak et al 2017). The plot of compressive strength against binder concentration showed that for all samples, particle size $\mathrm{X}=600 \mu \mathrm{m}$ retained gave higher strength when compared with $\mathrm{Y}=850 \mu \mathrm{m}$ (Fig 5). 
DOI: $10.17148 /$ IARJSET.2021.8465

Binder concentration $30 \% \mathrm{w} / \mathrm{v}$ from the graph gave the highest strength and it showed that further binder addition tends to a negative or a waste of material. It was observed that the binder concentration of less than $20 \%$ had very low mechanical strength was not reported. The Ultimate comprehensive of the samples at $30 \%$ w/v was plotted which showed that sample B Cordina milleni (Omo Sheda) had the best strength (Fig 6).

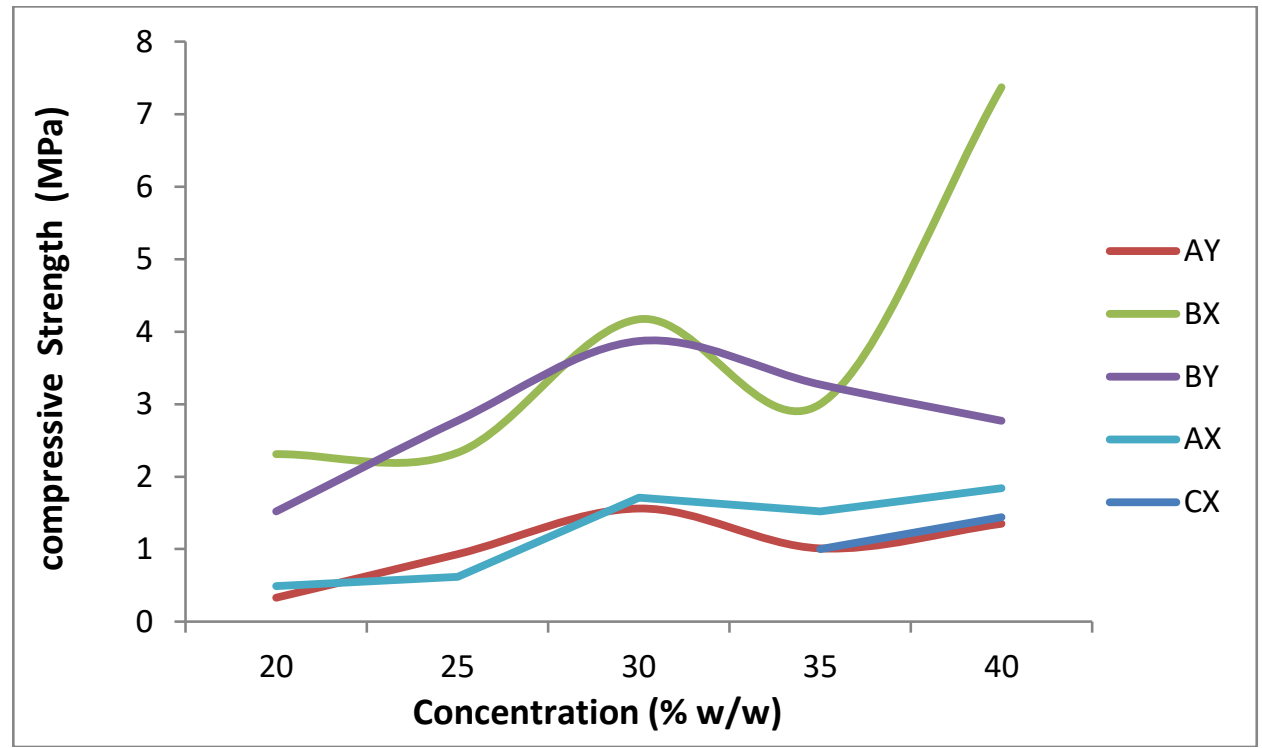

Figure 5. Compressive Strength of the samples at different concentrations

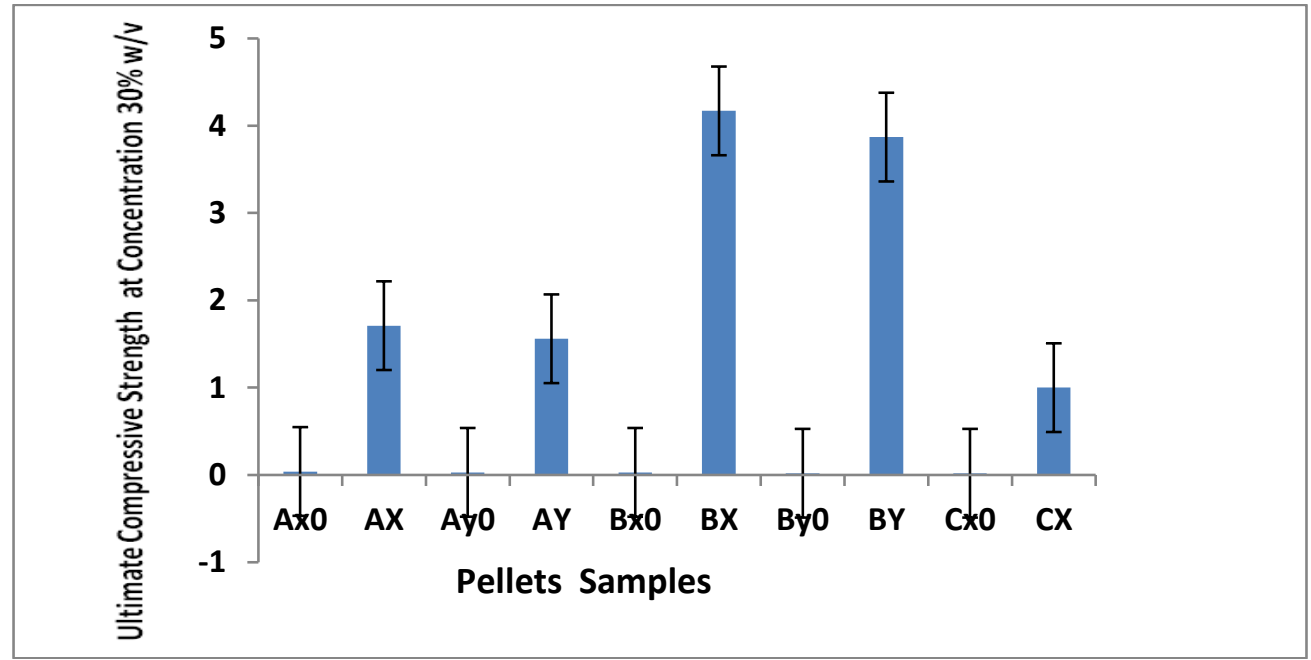

Figure 6: Ultimate Compressive Strength at the Concentration of 30\% w/v.

\section{Combustion Test}

It was observed that each of the five (5) pellets used weighed differently depending on the concentration of the binder and wood type as recorded in table $5 \mathrm{a}$ and $5 \mathrm{~b}$, the weight ranged between $0.28 \mathrm{~kg}-0.40 \mathrm{~kg}$. The flame temperature gradually increased from ambient temperature and starts decreasing as the water boils. The maximum flame temperature has its range between $601^{\circ} \mathrm{C}-306^{\circ} \mathrm{C}$. The ignition time was the same as all wood samples. Pellet with binder concentration $40 \% \mathrm{w} / \mathrm{v}$ having higher density had longer burnout time for all three samples [Acda and Devera, 2014] with sample B (Cordina milleni) having the longest burnout time and duration but gave the highest smoke emission compared to the other samples. Pellets with a lower concentration of binder (20\%w/v) burns off faster and have a shorter duration for burning (Onukak et al., 2017). It was observed that sample C (mixed sawdust) required more pellets to sustain the flame having the shortest duration and burnout time (Liu et al., 2014).

The efficiency of combustion of densified materials such as pellets and briquettes depends on the moisture content, the chemical composition which is a function of the biomass type, and the density of the material (Aashosh and Summet, 2014). Particle size $600 \mu \mathrm{m}$ was selected for the test because it had a higher density. The calibration of the 
International Advanced Research Journal in Science, Engineering and Technology

Vol. 8, Issue 4, April 2021

DOI: $10.17148 / I A R J S E T .2021 .8465$

thermocouple as recorded in Table 3 showed the melting point of known chemicals in agreement with the thermocouple reading.

Table 3: The calibration test for the thermocouple

\begin{tabular}{lccl}
\hline Standard Chemicals & Melting point $\left({ }^{\circ} \mathbf{C}\right)$ & Type k Thermocouple $\left({ }^{\circ} \mathbf{C}\right)$ & Observations \\
\hline Environment & 28 & 28 & Warm Day \\
Benzoic Acid & 128 & 128 & White powder turned clear \\
Solder (alloy of $\mathrm{Pb} \& \mathrm{Sn})$ & 430 & 423 & Melted \\
Zinc granules & 500 & 500 & Melted into ashes \\
Melting Point glass & $560-570$ & 560 & Bent \\
Magnesium ribbon & 651 & 648 & Deflagrated with a blinding \\
\hline
\end{tabular}

Table 4. Combustion Test Cetis Africana (Ita white)

\begin{tabular}{|c|c|c|c|c|c|c|c|}
\hline Pellet & & & $A=$ Cetis & fricana (Ita $\mid$ & iite) & & \\
\hline $\begin{array}{l}\text { Binder Conc } \\
(\% \mathrm{w} / \mathrm{w})\end{array}$ & $\begin{array}{l}\text { No of } \\
\text { Pellets }\end{array}$ & $\begin{array}{l}\text { Volume of water } \\
\text { (1) }\end{array}$ & $\begin{array}{l}\text { Ignition Time } \\
t_{2}=\left[t_{1}-t_{0}\right](\min )\end{array}$ & $\begin{array}{c}\text { Boiling } \\
\text { Time } \\
{\left[\mathrm{t}_{3}-\mathrm{t}_{2}\right](\mathrm{min})}\end{array}$ & $\begin{array}{c}\text { Total } \\
\text { Duration } \\
{\left[\mathrm{t}_{4}-\mathrm{t}_{1}\right](\mathrm{min})}\end{array}$ & $\begin{array}{l}\text { Smoke } \\
\text { Emission }\end{array}$ & $\begin{array}{c}\text { Boiling } \\
\text { Temperature } \\
\left({ }^{\circ} \mathrm{C}\right)\end{array}$ \\
\hline 20 & 5 & 2 & 6 & 12 & 37 & Low & 97 \\
\hline 30 & 5 & 2 & 6 & 11 & 40 & Low & 97 \\
\hline 40 & 5 & 2 & 7 & 9 & 47 & Very low & 97 \\
\hline $\begin{array}{l}\text { Particle Size } \\
\text { Table 5.Comb }\end{array}$ & $\begin{array}{l}\mathrm{K}=\mathbf{6 0 0} \boldsymbol{\mu 口} \\
\text { istion Tes }\end{array}$ & $\begin{array}{l}\text { nbient Temperat } \\
\text { ina milleni }(\mathrm{Omo}\end{array}$ & $\begin{array}{l}e=27^{\circ} \mathrm{C} \\
\text { eda) }\end{array}$ & & & & \\
\hline Pellet Sample & & & $B=$ Cordin & Milleni (Om & Sheda) & & \\
\hline $\begin{array}{l}\text { Binder Conc } \\
(\% \mathrm{w} / \mathrm{w})\end{array}$ & $\begin{array}{l}\text { No of } \\
\text { Pellets }\end{array}$ & $\begin{array}{l}\text { Volume of } \\
\text { water (l) }\end{array}$ & $\begin{array}{l}\text { Ignition Time } \\
t_{2}=\left[t_{1}-t_{0}\right](\min )\end{array}$ & $\begin{array}{c}\text { Boiling } \\
\text { Time }\left[\mathrm{t}_{3^{-}}\right. \\
\left.\mathrm{t}_{2}\right](\mathrm{min})\end{array}$ & $\begin{array}{c}\text { Total Duration } \\
{\left[\mathrm{t}_{4}-\mathrm{t}_{1}\right](\mathrm{min})}\end{array}$ & $\begin{array}{l}\text { Smoke } \\
\text { Emission }\end{array}$ & $\begin{array}{c}\text { Boiling } \\
\text { Temperature } \\
\left({ }^{\circ} \mathbf{C}\right)\end{array}$ \\
\hline 20 & 5 & 2 & 6 & 16 & 39 & Very high & 97 \\
\hline 30 & 5 & 2 & 6 & 14 & 44 & High & 97 \\
\hline 40 & 5 & 2 & 6 & 13 & 49 & $\begin{array}{l}\text { Moderatel } \\
\text { y high }\end{array}$ & 97 \\
\hline
\end{tabular}

\section{Particle Size $X=600 \mu \mathrm{m} ;$ Ambient Temperature $=27^{\circ} \mathrm{C}$}

\section{Surface Analysis}

It was observed that the raw sample had more pores when compared with XA1 and XA3. XA3 showed more binder cementing when compare to the others XA3 $>$ XA1 $>$ XA0. This was also observed for the other samples B and C such that $\mathrm{XB} 3>\mathrm{XB} 1>\mathrm{XB} 0$. Comparing the particle sizes $\mathrm{Y}(850 \mu \mathrm{m}$ retained $)$ and $\mathrm{X}(600 \mu \mathrm{m}$ retained $)$ for samples $\mathrm{A}$ and B. It was observed that $\mathrm{X}(600 \mu \mathrm{m}$ retained) had more cementing and better binding than $\mathrm{Y}(850 \mu \mathrm{m}$ retained $)$.

This confirms that binders help to cement particles of the feed materials used for pellets formation in agreement with Qiang et al., 2015. This effect is increased when particle size is reduced and as binder concentration is increased and in turn, the compressive strength is increased. The result also confirms that the pellets formed had a good mechanical property that reduces the risk of breakage during handling, transportation, and storage. These pellets will be efficient for use in pellet stoves and have the good potential not to disintegrate and cause system blockage when used in hightemperature furnaces such as a gasifier. 


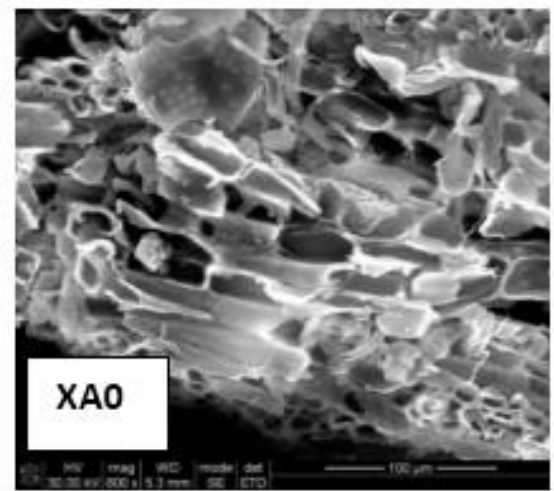

DOI: $10.17148 / I A R J S E T .2021 .8465$
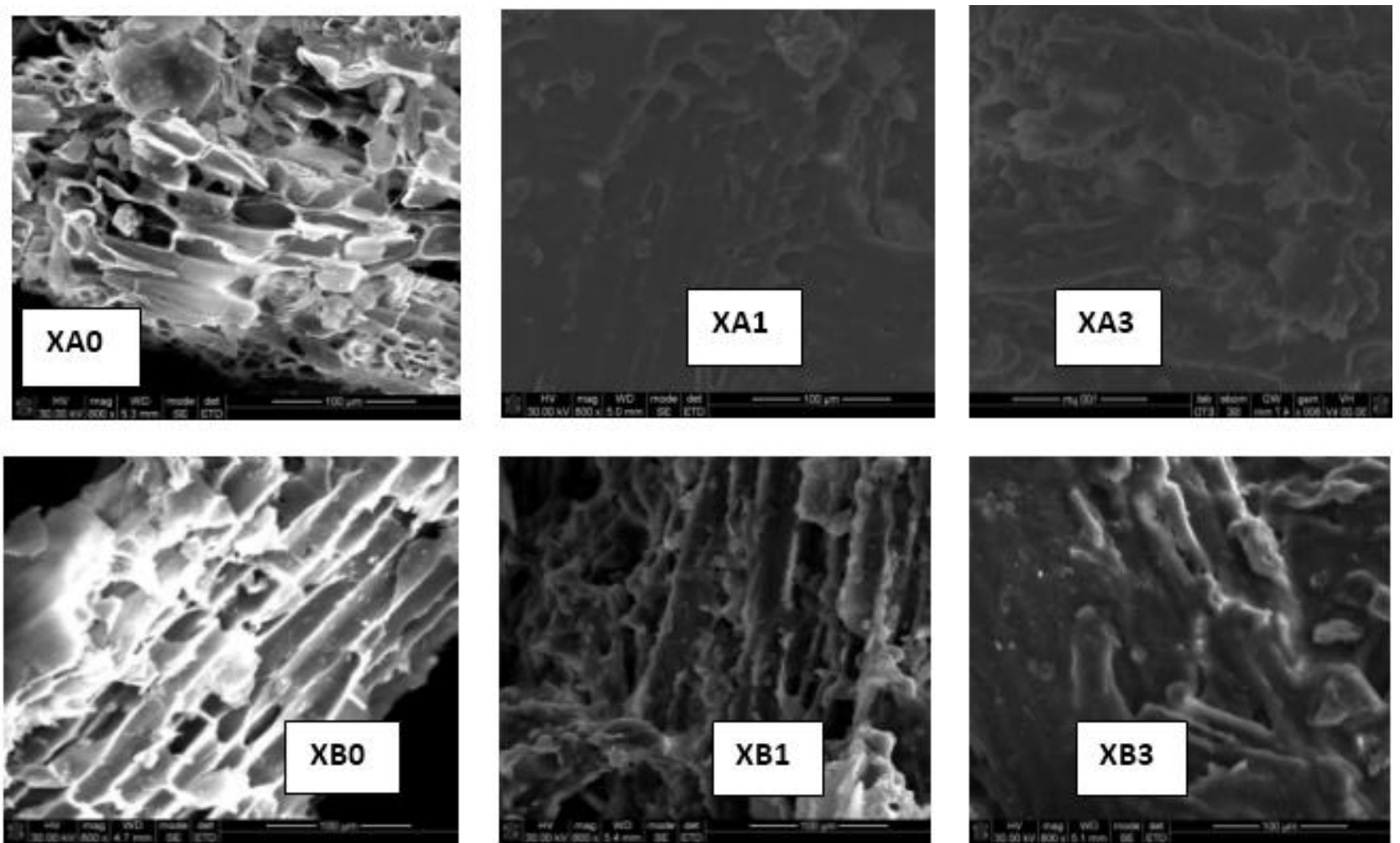

\section{Calorific Value}

The energy value of the raw wood waste and pelletized wood waste made at different binder concentration as determined using a bomb calorimeter and result presented in Table 5 showed that binder concentration does not really have significant effect on the calorific value of the pellets owing to the overall low percentage content of the binder to the water and the sample (Kuokkanen et al., 2011). Pelletisation affects moisture content but not the energy density on a dry basis. It does not affect the energy content. So, the mass-energy density of pelletized wood is the same as the feed wood as-received but the volume energy density is not the same (Basu, 2013).

Table5: Calorific Value of Raw and Pelletized wood waste

\begin{tabular}{lccc}
\hline $\begin{array}{c}\text { Binder Conc } \\
(\boldsymbol{\%} \text { w/w) }\end{array}$ & $\begin{array}{c}\text { Sample Code } \\
\text { Particle size } \mathbf{X}=\mathbf{6 0 0} \boldsymbol{\mu m}\end{array}$ & $\begin{array}{c}\boldsymbol{A}=\text { Cetis Africana } \\
\text { Calorific Value }(\mathbf{M J} / \mathbf{K g})\end{array}$ & $\begin{array}{c}\text { B =Cordina Milleni } \\
\text { Calorific Value }(\mathbf{M J} / \mathbf{K g})\end{array}$ \\
\hline $\mathbf{0}$ & XA , XB (Raw & 17.227 & 17.202 \\
$\mathbf{0}$ & Calculated (Raw sawdust) & 15.700 & 16.960 \\
$\mathbf{3 0}$ & XB3 , XA3 & 16.106 & 17.251 \\
$\mathbf{3 5}$ & XA4 , XB4 & 16.277 & 16.232 \\
$\mathbf{4 0}$ & XA5 , XB5 & 16.357 & 16.554 \\
\hline
\end{tabular}

Effect of Biomass Type on Quality of Pellets.

For the samples selected for work, the major constituents are as shown in Table 6.

Table 6: Chemical composition of the pellets

\begin{tabular}{lccc}
\hline Samples & Cellulose & Hemicelluloses & Lignin \\
\hline A & $36.80 \pm 3.76$ & $31.00 \pm 1.41$ & $22.00 \pm 2.63$ \\
B & $35.95 \underline{ \pm 0.26}$ & $32.00 \pm \underline{+2.83}$ & $18.54 \underline{+2.35}$ \\
C & $37.94+3.73$ & $28.50 \pm \underline{+2} .12$ & $25.13+2.42$ \\
\hline
\end{tabular}

Adapa et al., 2013pointed out that biomass type is the most significant factor that affects the quality of pellets. Moisture plays a major role in determining pellet property (Onukak et al., 2017; Garcia Maraver A and Carpio M., 2015). High moisture content reduces the binding strength as well as the density. This was observed as sample A with MC\% of $10.85 \pm 2.24$ had higher density when compared with sample B with MC\% of 11.28 \pm 0.57 . Sample B is also a dark wood, it produced more emission and odour during the combustion test. The wood with more odour, has more volatile 


\section{International Advanced Research Journal in Science, Engineering and Technology}

Vol. 8, Issue 4, April 2021

\section{DOI: $10.17148 /$ IARJSET.2021.8465}

compound present. The darker or richer the colour of wood, the more extractives present in the wood (Reeb and Milota, 1997). Colour of wood sample helps us to give an estimation of the properties and quality of pellet fuels such as the heating value (Lam and Sokhansanj, 2014)

Sample $\mathrm{C}$ which is the mixed sawdust gave varying results. It requires more pellets to burn and it has a short burn out time. (Liu et al., 2014). This confirms that pellets should be made from single wood species per time or mixed on purpose after carefully understanding the characteristics of the individual raw material. This agreed with the report of Link and his team in 2013 that the interaction between the chemical properties of different biomass fuel gives problematic results even to the end product and use of the pellets except there is sufficient investigation of the individual samples before the combination (intentional mixing).

\section{Effect of Particle size on quality of Pellets}

As was observed, drying and sieving were the only pretreatments done on the sample of sawdust selected for this work since the extent of grinding depends on the feedstock (Whittaker and Shield, 2017). The selected particle size as seen in the table $(\mathrm{x} \leq 600 \mu \mathrm{m})$ and $(\mathrm{y} \leq 850 \mu \mathrm{m})$ was the recommended particle size for a good densification process (Khan et al., 2017; Onukak et al., 2017). Arzola et al., 2012 concluded that particle size had a greater influence on pellet quality than binding agent content or concentration. The results presented showed that particle size $X=600 \mu \mathrm{m}$ retained had higher density, higher compressive strength for the three (3) sawdust samples (AX, BX, and CX), when compared to Y $=850 \mu \mathrm{m}$, retained (AY, BY, and CY). Particle size has a strong influence on the pellet density of both wood and nonwood biomass (Harun et al., 2008; Miranda et al., 2015).

Results for CY (mixed samples with $850 \mu \mathrm{m}$ particle size) were not reported because the pellets were coarse and had cracks and fractures. This confirms that large particle size causes cracks and fracture on pellets as well as low fusion point as reported by (Onukak et al., 2017; Malik et al., 2015). This is worse especially when proper cooling is not achieved as was observed. There will be stresses appearing between the inner (warm or wet) and the outer (cold/dry) part of the pellets. (Malik et al., 2015; Whittaker and Shield, 2017). All this invariably affects the mechanical strength and ultimately the quality of the pellets formed.

With finer the particle size, the compaction process is made easier, and the larger the surface area for bonding. (Onukak et al, 2017; Whittaker and Shield, 2017). This confirms the need for pre-treatment such as drying, grinding, and/or sifting before pelletizing operation for high-quality pellets (Miranda et al, 2015, Adapa et al, 2013; Katimbo et al, 2014; Malik et al, 2015). The combustion property of particle size of $850 \mu \mathrm{m}$ was not considered. The denser particles were observed to be the $600 \mu \mathrm{m}$ and they also had longer burn out time.

\section{CONCLUSION}

Biomass waste conversion to pellet fuel is an innovative project. It was concluded that the higher the concentration of the binder, the cementing of the sawdust particles and the higher the density of the pellets but the compressive strength showed that there is an optimal point where an increase in concentration does not amount to strength but waste of resources as can be seen from the graph of compressive strength against concentration, 30\% w/v gave the highest strength and energy at break for samples, A and B but C energy was not highest at $30 \%$.

For both types, density increased as the binder concentration increased with sample A particle size $600 \mu \mathrm{m}(\mathrm{AX} 5=$ $40 \% \mathrm{w} / \mathrm{v}$ ) and BX5 having 684.5 and $692.80 \mathrm{~kg} / \mathrm{m} 3$ respectively as the highest densities though it may not be the strongest compacted as shown by the compression strength. Also for both sample type A \& B, particle size (X) $600 \mu \mathrm{m}$ retained had the highest density when compared with (Y) $850 \mu \mathrm{m}$ retained. This also affects the combustion properties of the pellets.

From the ultimate compressive strength sample B Cordina milleni (Omo Sheda) had the highest strength but considering the result during combustion test and having the issue of environmental friendliness as part of the central reason for this research, Sample A will be preferred to B. SampleA which is Cetis africana (Ita white) at the optimal concentration of $30 \%$ and the best particle size of $600 \mu \mathrm{m}$ retained gave the best shape factor of 2.80, and the highest density of $647 \mathrm{~kg} / \mathrm{m}^{3}$ having less smoke when compared with Sample B Cordina milleni (Omo Sheda). Sample C which is the mixed wood gave results that did not agree with the other individual and this cannot be depended upon. This helps to conclude that to get a good result and high energy for pellets and other densified materials saw millers must be advised to separate their waste.

\section{REFERENCES}

[1]. Adapa P.K., Tabil L.G., Schoenau G.J. (2013). Factors Affecting the Quality of Biomass Pellets for Biofuel and Energy Analysis of Pelleting Process. International Journal of Agriculture and Biofuel and Energy, 6(2): 1-12. - doi:10.3965/j.ijabe.20130602.001.

[2]. Ajobo J.A. (2014) Densification characteristics of Groundnut Shell International Journal of Mechanical and Industrial Technology (2)1:150154. (ISSN: 2348-7593): www.researchpublic.com

[3]. Alejandro A., Mariana C., Andres C., Jorge D.V., Andres S., Nestor T. (2015). Preparation of Charcoal Pellets from Eucalyptus Wood with Different Binders Journal of Energy and Natural Resources 4(2): 34-35. 


\section{International Advanced Research Journal in Science, Engineering and Technology}

Vol. 8, Issue 4, April 2021

\section{DOI: $10.17148 /$ IARJSET.2021.8465}

[4]. Arzola N., Gomez A. and Rincoin S. (2012). The Effect of Moisture content, Particle size and Binding Agent content on Oil palm shell pellet quality parameters. Ingenieria investigacion vol.32 No.1- 24-29

[5]. Biswas A.K and Umeki K (2015) Simplification of Devolatilization Models for Thermal-Thick Particles: Differences between wood logs and pellets. Chemical Engineering Journal 274: 181-191

[6]. Brandin J, Tunrer M. and Odenbrand I. (2011) Small Scale Gasification: Gas Engineer CHP for Biofuels Linnaeus University, ISBN: 978 - 91 86983 - 07- 9 .

[7]. Chitedze J., Maurice M.D., Kalenga S. and Jan S. (2012). Binding Effect of Cassava Starches on the Compassion and Mechanical Properties of Ibuprofen Tablets Journal of Applied Pharmaceutical Science (2)4: 31-37 - doi:10.7324/JAPS.2012.2402.

[8]. Gracia-Maraver A. and Carpio M., (2015) Factors Affecting Pellet Quality. WIT Transaction on State of the Art in Science and Engineering, (85) WIT press. www.intpress.com doi:10.2495/978-1-84566-062-8/002.

[9]. HarunY.N., Parvez A.M. and Afzal T.M., (2018). Process and Energy Analysis of pelleting Agricultural and Woody Biomass Blend. Sustainability 10: 1770. - doi:10.3390/su10061770.

[10]. Lam P.S and Sokhansanj S. (2014). Engineering Properties of Biomass Engineering and science of Biomass feed stock production and provision, DOI 10.1007/978-4899-8014-4 -2 @ Springer Science + Business Media New York

[11]. Link S., Kask U., Paist A., Siirde., Arvelakis S., Hupa M., Yrjas P, and Kulasts I. (2013) Reed as a Gasification Fuel: a Comparison with Woody Fuels Mires and Peat (13)4: 1-12 http://www.Mires - and - peat.net/ISSN 1819 -754 x @ 2013 International Mire Conservation Group and International Peat Society.

[12]. Lisowski A., Matkowski P., Dabrowska M., Piatek M., Swietochowski A., Klonowski J., Mieszkalski L. and Reshetiuk V. (2018) Particle Size Distribution and Physicochemical Properties of Pellets Made of Straw, Hay and their Blends. Waste and Biomass Valorisation https://dio org/10.1007/5 12649-018-0458-8

[13]. Malik B., Pirzadah T.B., Islam S.T., Kumar M., Rehman R.U. (2015) Biomass Pellet Technology: A Green Approach for Sustainable Development. Springer International Publishing Switzerland Agricultural Biomass Potential Material: 403-433. DOI: 10.1007/978-3-319-13847-3-19.

[14]. McClure Laura (2015) Meet the First Cohort of TED-ED Innovative Educators! TED - Ed Innovative Educators Blog . blog.ed/Com/2015/09/01/meet-the-first-cohort- of -led-ed-innovative /educators/ Sourced August 2020.

[15]. Miranda T., Montero I., Sepintreda F., Arranz J., Rojas C.V. and Nogales S. (2015). A Review of Pellets from Different Sources Materials (8): 1413-1427; doi: 10.3390/ma 8041413.

[16]. Mitchual S. (2014). Densification of Sawdust of Tropical Hardwoods and Maize cobs at Room Temperature using Low compacting Pressure without a Binder. PhD Thesis Wood Science and Technology Faculty of Renewable Natural Resources, College of Agriculture and Natural Resources.

[17]. Stahl M., Berghel J., Frodeson S., Grawtron K and Renstrom R (2012) Effect on Pellet Properties and Energy use when Starch is added in the Wood Fuel Pelleting Process. Energy Fuels 2(3): 1937 - 1945

[18]. Okorie N.N, Kwa D.Y, Olusunle S.O.O, Akinyanmi A.O, Momoh I.M (2014), Technopreneurship: An Urgent Need In The Material World For Sustainability In Nigeria. European Scientific Journal vol.10, No.30, pg 69-73.

[19]. Qiang H., Shao J., Yang H., Yao D., Wang X., and Chen H. (2015) Effect of binders on Properties of Biochar Pellets. Applied Energy157,508516 www.elsevier.com/locate/apenergy.

[20]. Rajalingam K. (2014) View From The Crow's Nest: The role of technoprenuers in crafting an ethical business climate - with a special emphasis on nanotechnology, The Macrotheme Review A multidisciplinary journal of global macro trends. Review 3(2), pg 120 -128.

[21]. TumuluruJ., Wright C., Hess R. and Kenny K., (2011) A Review of Biomass Densification systems to Develop Uniform feedstock Commodities for Bioenergy Application. Doi:10.1002/bbb.324; Biofuels, Bioprod. Bioref 5: 683-707

[22]. Tumuluru J. S. (2014) Effect of Process Variables on the Density and Durability of the Pellets made from High Moisture Corn Stoves Biosystem Engineering $119: 44-57$ - http://dx.doi.org/10.1016/j.biosystemseng. 2013.11.012

[23]. Tumuluru J. S. (2018) Effect of Pellet Die Diameter on Density and Durability of pellets made from High Moisture Woody and Herbaceous Biomass. Carbon Resources Conversion $1 ;$ 44-54. www.keaipublishing.com/en/journals/carbon-resources-conversion/

[24]. Lu D.H., Tabil L.G., Wang D.C., Wang G.H., Wang Z.Q. (2014), Optimization of Binder Addition and Compression Load for Pelletisation of wheat straw using response surface methodology. International Journal of Agriculture and Biofuel Energy (7)6: 67-78 - http://www.ijabe.org.

[25]. Jindapon J. And Charroenpon L. (2017). Influences of Mixing Ratio and Binder Types in Properties of Biomass Pellets. Energy Procedia 138 pg 1147-1152

[26]. Koukouzas N., Flueraru C., Katsiadakis A., Karlopoulos E.(2008). Fixed Bed Gasification of Biomass fuel: Experimental Results. Energy for Sustainable Future. ISBN 978-963-9696-38-9.

[27]. Khan H.M., Zafar S., Ali C.H., Igbal T., Imitiaz M.A. (2017). Densification Characteristics of Bagasse Using Starch Based Natural and Synthetic Binder Journal of Pakistan Institute of Chemical Engineers (45)1:100-112.

[28]. Ungureanu N., Vladnt V., Voicu G., Dinca M. and Zabava B. (2018). Influence of Biomass Moisture Content on Pellet Properties - Review. Engineering and Rural Development Jelgava, 23-25.05. doi:10.22616/ERDev 2018.17.N449

[29]. Whittake and Shield (2017), Factors affecting wood, energy grass and straw pellet durabiliyty - A review. Renewable and Sustainable Energy Reviews (http://dx.doi.org/10.1016/j.rser. 2016.12.119) 